\title{
Applying modern technologies when drilling directional wells with long horizontal boreholes
}

\author{
Aleksandr E. Kuriachii ${ }^{*}$, Sergei M. Kaliagin ${ }^{1}$ \\ ${ }^{1}$ Astrakhan State Technical University, Astrakhan, Russia \\ *e-mail: kuryachiy.aleksandr@mail.ru
}

\begin{abstract}
Introduction. Directional drilling of wells is currently carried out by a rotary steerable system and conventional equipment including a mud motor with an adjustable skew angle. Either of the two methods has particular advantages.

Research aim is to analyze the technologies provided by various service companies in the field of directional and horizontal wells drilling in order to provide means of improving the utilization capacity of the conventional bottom hole assembly in long horizontal boreholes.

Methodology. When drilling directional wells with a small departure from the vertical and wells with horizontal boreholes up to $500 \mathrm{~m}$ long, a preference is given to a mud motor as far as a change in deviation parameters is concerned. This is due to the fact that the mud motor has a significant economic advantage. However, when drilling directional well with complex planned profile or a well with a horizontal borehole of more than $500 \mathrm{~m}$, the mud motor may cause a variety of problems, while a rotary steerable system will allow to avoid some of them.

Results. The rotary steerable system is not always economically feasible suggesting a need for an alternative technology with a more advantageous offer on the market of services. A system of pulsed controlled drilling will allow the adjustment of the trajectory of the wellbore when drilling in a rotary mode with conventional equipment for directional drilling, reduce rig time, and improve the borehole quality.

Summary. The given technology will make it possible to improve the efficiency of conventional equipment which includes the mud motor for directional wells drilling with complex planned profile and long horizontal boreholes of more than $500 \mathrm{~m}$, as soon as the technology provides the possibility of adjusting the trajectory in a rotary mode. The system of pulsed controlled drilling is developed as an alternative to the rotary steerable system making it possible to significantly reduce construction expenses for wells with complex geological conditions of drilling.
\end{abstract}

Key words: system of pulsed controlled drilling; rotary steerable systems; buckling effect; sliding; traditional bottom hole assembly; trajectory correction.

Introduction. Directional drilling of wells is currently carried out by a rotary steerable system (RSS) and conventional equipment including a mud motor with an adjustable skew angle (MM). Either of the two methods has particular advantages. The main advantage of RSS over MM is the availability of directional drilling in rotor mode. It makes it possible to reduce friction of a drilling string on the walls of the well by means of its continuous rotation. Rotary steerable system in the bottom hole assembly (BHA) totally eliminates directional drilling in sliding mode. The main advantage of MM over RSS is its economic feasibility. Daily rental fee for MM is tenfold cheaper than RSS daily rental fee. As a result, well construction expenses are reduced [1].

Research aim is to analyze technologies provided by various service companies in the field of directional and horizontal wells drilling in order to provide means of improving the utilization capacity of the conventional BHA in long horizontal boreholes.

Methodology. When applying MM in the bottom hole assembly, the process of directional drilling is carried out by means of sliding when the bottom hole assembly is 
motionless in the borehole. In this case, as compared to rotation, it is much more difficult to overcome the force of friction in horizontal boreholes with large departure from the vertical. A problem arises of bringing the required and smooth load to drill bits, there are occasional shutdowns and failures of the assembly; there is also an increasing possibility of differential pressure sticking in the layers which are inclined to drilling mud absorption. A system of pulsed controlled drilling is a solution to these problems. The technology will make it possible to increase the effectiveness of conventional equipment when drilling directional wells with long horizontal boreholes and reduce expenses [2].

When drilling directional wells with small departure from the vertical and wells with horizontal boreholes up to $500 \mathrm{~m}$ long, a preference is given to $\mathrm{MM}$ as far as a change in deviation parameters is concerned. This is due to the fact that MM has a significant economic advantage. However, when drilling directional well with complex planned profile or a well with a horizontal borehole of more than $500 \mathrm{~m}, \mathrm{MM}$ may cause a variety of problems.

Firstly, it is the problem of bringing the required and smooth load to a drill bit due to the significant friction factor in the sliding mode and, as a consequence, a developed buckling effect. Drilling efficiency reduces significantly, orientation time increases, and additional conditioning of a borehole and unplanned round trip operations become a necessity. So, for trouble-free well drilling with complex planned profiles and long horizontal boreholes of more than $500 \mathrm{~m}$, a rotary steerable system is used to be able to adjust the trajectory when drilling in rotor mode [3].

When drilling in rotor mode, rock breaking is uneven as soon as the drilled layers are not always uniform with frequent shelly formations. As a result, the drill bit and the whole BHA may deviate in various directions with an impressive dogleg severity. Pendulum BHA is an exception. This is due to the fact that the drill bit moves in the direction of least resistance where it is easier to mine out the rock. The system of pulsed controlled drilling makes it possible to mine out more rock in rotor mode in the required area, which allows to adjust the trajectory of the borehole in rotor mode when using MM with an adjustable skew angle [4].

The main goals of applying the system of pulsed controlled drilling are the following: control over the trajectory during rotor drilling, use of conventional equipment for directional drilling, reduction of rig time, and improved quality of the borehole.

Results. The system of pulsed controlled drilling was developed in 2010 by Weatherford company which carried out successful tests in the shafts of Oklahoma, Utah, Texas, and Pennsylvania, having drilled more than 45 thousand meters with this system. The system of pulsed controlled drilling was used in vertical wells to sustain perpendicularity, at stabilization sections in order to maintain the preset parameters of the trajectory, and in deviation intervals where the dogleg severity of $1 \% / 10 \mathrm{~m}$ was obtained [5].

In Oklahoma, $2469 \mathrm{~m}$ deep vertical well was drilled. The system of pulsed controlled drilling was used in the second run with the space interval of 1125-2469 m. This space interval was mainly formed with sandstone, and it was drilled in one round trip operation with average speed of $45 \mathrm{~m} / \mathrm{h}$. In the same cuts BHA with rotary steerable system shows lower speed of drilling due to the difference in the number of drilling bit turns. Having included the rotary steerable system into BHA, the customer could reduce time spent to adjust the whipstock in the required direction, and it made it possible to reduce well construction expenses by 200 thousand US dollars.

BHA consisted of the following elements (fig. 1):

1. Drill bit PDC $215.9 \mathrm{~mm}$ (152 $\mathrm{mm}$ gage surface length);

2. Motor WF 675-QLE7850 (172 mm), $1.5^{\circ}$ skew angle; 
3. Adjustable centralizer AGS;

4. Pulsator;

5. HEL telemetry system (inclinometer, gamma radiation sensor);

6. Drilling jar.

The main advantages and characteristic features of applying the system of pulsed controlled drilling are the following: automatic regulation of vertical; spiral and axial load reduction ensuring high-quality drilling of a directional hole; drilling build sections and stabilization intervals in one run with the use of one BHA; drilling by a rotor method at complicated sites maintaining the planned parameters of the trajectory; increasing the speed of drilling and improving borehole quality by reducing sliding operations; reducing slide/rotor ratio to $4 / 96 \%$; rig time reduction; well expenses reduction [6].

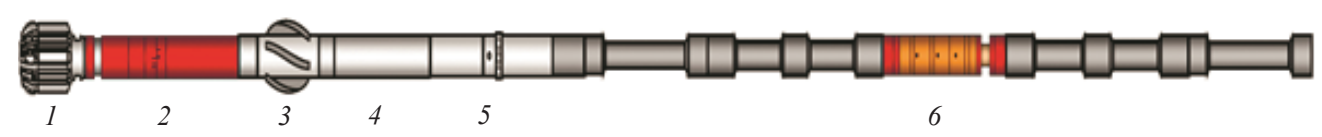

Fig. 1. Typical design of BHA

Рис. 1. Типовая схема КНБК

A mud motor with an adjustable skew angle is the basis of the system of pulsed controlled drilling; it works along two various drilling centerlines (rotational and orienting). Controlled adjustment of drill bit rotation speed through the motor contributes to change in the trajectory of a borehole (fig. 2) [7].

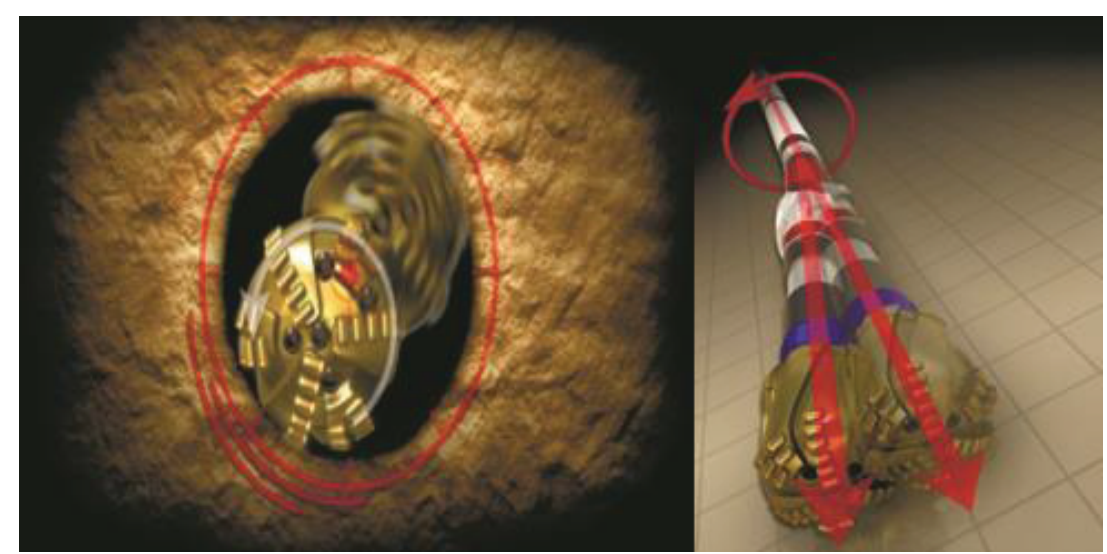

Fig. 2. Principle of operation of a downhole motor with an adjustable skew angle

Рис. 2. Принцип работы винтового забойного двигателя с регулируемым углом перекоса

The speed of drill bit rotation when drilling with the use of MM depends on the speed of the drilling mud which passes through it. The pulsator set lower than the telemetry system controls the speed of the passing flow by means of partial overlap of the tube side.

With the closed pulsator, drill bit rotation speed and drilling speed decreases [8]. With the open pulsator, drill bit rotation speed and drilling speed increases (fig. 3).

Every particular component influences the technological efficiency, namely, drill bit, hydraulic bottomhole motor, stabilizator, and MWD instrument.

The use of conventional hydraulic bottomhole motors and MWD instruments is possible with the reliability confirmed by tests, under total three-dimensional control 
over the directional drilling. If necessary, it is possible to stop drilling and give the right orientation to the assembly to obtain a higher dogleg severity using the method of traditional directional drilling [9].

There are two methods of reprogramming the pulsator: by issuing a command to change the speed of rotor rotation and with the help of Down Link Commander system with the difference of pressure change.

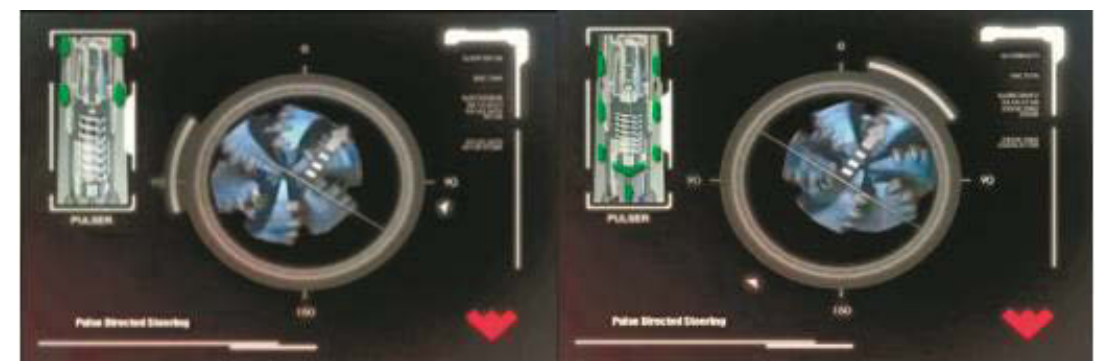

Fig. 3. The principle of operation of the pulsator in the open/closed state

Рис. 3. Принцип действия пульсатора в открытом/закрытом состоянии

In case there is deviation from the trajectory in the process of rotary drilling, a command is issued to the pulsator due to the difference in rotor turns or difference in pressure for work in a desired direction; after that the pulsator starts opening in a desired sector increasing the speed of the drilling mud which passes through it, thereby increasing MM shaft speed; finally, the pulsator closes reducing rotation rate at the counter side [10].

Summary. The given technology [11-15] will make it possible to improve the efficiency of conventional equipment which includes MM for directional wells drilling with complex planned profile and long horizontal boreholes of more than $500 \mathrm{~m}$, as soon as the technology provides the possibility of adjusting the trajectory in a rotary mode. The system of pulsed controlled drilling is developed as an alternative to the rotary steerable system making it possible to significantly reduce construction expenses for wells with complex geological conditions of drilling.

\section{REFERENCES}

1. Dzhalmukhanova R. I., Kuriachii A. E. The use of modern technological tools to reduce the friction coefficient of the drill string during the construction of directional and horizontal wellbores in LLC LUKOIL-Nizhnevolzhskneft. In: New technologies for the development of hydrocarbon deposits and provision ecosystem safety of the Caspian shelf: Proceedings of the VII International Scientific and Practical Conference. Astrakhan: ASTU Publishing; 2016. P. 40-44. (In Russ.)

2. Egorova E. V., Iazykov I. V. Optimization offshore development of multilateral wells. Geologiia, geografia $i$ globalnaia energiia = Geology, geography and global energy. 2014; 3 (54): 210-213. (In Russ.)

3. Shaikhutdinova A. F., Khuzina L. B. Field tests the bottom hole assembly with PDC bits. In: Proceedings of the scientific session of scientists of the Almetyevsk State Oil Institute. 2015; 1 (1): 79-83. (In Russ.)

4. Technological complex for directional drilling with the use of MSS and AGS. Available from: www.weatherford.com/ru/products-services/drilling-formation-evaluation/ drilling-services. [Accessed 11 th March 2020].

5. Khuzina L. B., Liubimova S. V., Slivchenko A. F. Reducing friction during drilling. Business Journal Neftegaz.RU. 2016; 3: 38-41. (In Russ.)

6. Khuzina L. B., Liubimova S. V. Particularly lowering of stuck drill string. Uchenye zapiski Almetievskogo gosudarstvennogo neftianogo instituta = Proceedings of the Almetyevsk State Oil Institute. 2013; 11 (1): 58-63. (In Russ.)

7. Liu Xiushan, Su Yi'nao. A design method of borehole deviation control scheme. Acta Petrolei Sinica. 2015; 36(7): 890-896.

8. Liu Xiushan. Geometry of wellbore trajectory. Beijing: Petroleum Industry Press; 2006.

9. Popov A. N., Spivak A. I. The technology of drilling oil and gas wells. Moscow: Nedra Publishing; 2001. (In Russ.) 
10. Shi Hongxiang, Li Hui, Zheng Duoming, et al. Seismicguided drilling technique based on seismic while drilling (SWD): a case study of fracture-cave reservoirs of Halahatang block, Tarim Oilfield, NW China. Petroleum Exploration and Development. 2016; 43(4): 662-668.

11. Shevchenko I. A. Development of the technology of controlled rotary drilling in the construction of wells with a sub-horizontal profile. In: Technical Sciences in Russia and Abroad: Materials of the III Intern. scientific conf. (Moscow, July 2014). Moscow: Buki-Vedi Publishing; 2014. (In Russ.)

12. Kane S. A. Modern technical means of controlling the trajectory of directional wells: study guide. Ukhta: USTU Publishing; 2014. (In Russ.)

13. Shirin-Zade S. A., Mirzadzhanzade A. H., Oganov A. S., Gulatarov G., Mirzadzhanzade A. H. Drilling of horizontal wells with an electric down hole motor. In: 14th World petroleum congress. 1994. P. 181-190.

14. Khuzina L. B., Liubimova S. V., Shaikhutdinova A. F. Technique for reducing friction forces when drilling horizontal sections of wells. Oilfield business = Oilfield Engineering. 2016; 9: 38-42. (In Russ.)

15. Oganov S. A., Baisarov E. E., Labazanov S. Kh. Achievement of high technical and economic indicators of horizontal wells construction. Problemy ekonomiki $i$ upravleniia neftegazovym kompleksom = Problems of Economy and Management of Oil and Gas Complex. 2012; 5: 126-132.

Received 7 April 2020

\section{Information about authors:}

Aleksandr E. Kuriachii - PhD student, Oil and Gas Institute, Astrakhan State Technical University. E-mail: kuryachiy.aleksandr@mail.ru

Sergei M. Kaliagin - PhD (Geology and Mineralogy), Associate Professor, associate professor of the Department of Oil and Gas Geology, Astrakhan State Technical University. E-mail: kalyagin-sergey@lenta.ru

\section{Применение современных технологических средств в области бурения наклонно-направленных скважин с протяженными горизонтальными стволами}

Курячий А. Е. ${ }^{1}$, Калягин С. М. ${ }^{1}$

${ }_{1}^{1}$ Астраханский государственный технический университет, Астрахань, Россия.

\section{Peфepam}

Введение. В настоящее время наклонно-направленное бурение скважин осуществляется в результате применения роторно-управляемой системь и традиционного оборудования, включающего винтовой забойный двигатель с регулируемым углом перекоса. Каждый из способов имеет определенные преимущества.

Цель работы. Проанализировать технологические средства различных сервисных организачий, предоставляющих услуги в сфере бурения наклонно-направленных и горизонтальных скважин, для обеспечения возможности увеличения потенциала использования традиционной компоновки низа бурильной колонны в протяженных горизонтальных стволах.

Методология. В условиях бурения наклонно-направленньх скважин с небольшим отходом от вертикали, а также скважин с горизонтальными стволами протяженностью до 500 м предпочтение для изменения параметров искривления отдается винтовому забойному двигателю. Это связано с тем, что применение винтового забойного двигателя является более доступным с экономической точки зрения. Однако при бурении наклонно-направленной скважины со сложным проектным профилем или скважины с горизонтальным стволом более 500 м, использование винтового забойного двигателя приведет к ряду осложнений, в то время как использование роторно-управляемой системы позволит избежать некоторых из них.

Результаты. Применение роторно-управляемой системы для бурения наклонно-направленных скважин с протяженными горизонтальными стволами не всегда экономически иелесообразно, $u$ поэтому существует необходимость в альтернативном технологическом подходе с более выгодным предложением на рынке предоставляемых услуг. Система импульсного управляемого бурения обеспечит управление траекторией в роторном режиме с использованием традиционого оборудования для наклонно-направленного бурения, сократит время бурения и повысит качество пробуренного ствола.

Выводы. Таким образом, применение данной технологии позволит повысить эффективность использования традиционного оборудования, включающего винтовой забойный двигатель для бурения наклонно-направленных скважин со сложными проектными профилями и протяженными горизонтальными стволами более 500 м за счет возможности управлять траекторией в роторном режиме. Система импульсного управляемого бурения разрабатьвается как альтернатива роторно-управляемой системе, ее использование позволит значительно сократить расходы на строчтельство скважин со сложными геологическими условиями бурения. 
Ключевые слова: система импульсного управляемого бурения; роторно-управляемая система; эффект баклинга; слайдирование; традиционная компоновка низа бурильной колонны; корректировка траектории.

\section{БИБЛИОГРАФИЧЕСКИЙ СПИСОК}

1. Джалмуханова Р. И., Курячий А. Е. Применение современных технологических средств для снижения коэффициента трения бурильной колонны при строительстве наклонно-направленных и горизонтальных стволов скважин в ООО «Лукойл-Нижневолжскнефть» // Новейшие технологии освоения месторождений углеводородного сырья и обеспечение безопасности экосистем Каспийского шельфа: матер. VII Междунар. науч.-практ. конф. Астрахань: АГТУ, 2016. С. 40-44.

2. Егорова Е. В., Языков И. В. Оптимизация разработкишельфовых месторождений многоствольными скважинами // Геология, география и глобальная энергия. 2014. № 3(54). С. 210-213.

3. Шайхутдинова А. Ф., Хузина Л. Б. Результаты промысловых испытаний компоновки низа бурильной колонны с долотом PDC // Матер. науч. сессии ученых Альметьевского госуд. нефтяного института. 2015. Т. 1. № 1. С. 79-83.

4. Технологический комплекс для наклонно-направленного бурения с применением MSS и AGS. URL: www.weatherford.com/ru/products-services/drilling-formation-evaluation/ drilling-services (дата обращения: 11.03.2020).

5. Хузина Л. Б., Любимова С. В., Сливченко А. Ф. Снижение трения при бурении // Деловой журнал Neftegaz.RU. 2016. № 3. C. 38-41.

6. Хузина Л. Б., Любимова С. В. Особенности снижения прихватоопасности бурильной колонны // Ученые записки Альметьевского государственного нефтяного института. 2013. Т. 11. № 1. С. $58-63$.

7. Liu Xiushan, Su Yi'nao. A design method of borehole deviation control scheme // Acta Petrolei Sinica. 2015. No. 36(7). P. 890-896.

8. Liu Xiushan. Geometry of wellbore trajectory. Beijing: Petroleum Industry Press, 2006.

9. Попов А. Н., Спивак А. И. Технология бурения нефтяных и газовых скважин. М.: Недра, 2001. C. 171-173.

10. Shi Hongxiang, Li Hui, Zheng Duoming, et al. Seismicguided drilling technique based on seismic while drilling (SWD): a case study of fracture-cave reservoirs of Halahatang block, Tarim Oilfield, NW China // Petroleum Exploration and Development. 2016. No. 43(4). P. 662-668.

11. Шевченко И. А. Развитие технологии управляемого роторного бурения при строительстве скважин с субгоризонтальным профилем // Технические науки в России и за рубежом: матер. III Междунар. науч. конф. (Москва, июль 2014 г.). М.: Буки-Веди, 2014. С. 331-336.

12. Кейн С. А. Современные технические средства управления траекторией наклонно направленных скважин. Ухта: УГТУ, 2014. С. 78-82.

13. Shirin-Zade S. A., Mirzadzhanzade A. H., Oganov A. S., Gulatarov G., Mirzadzhanzade A. H. Drilling of horizontal wells with an electric down hole motor // 14th World petroleum congress. 1994. P. 181-190.

14. Хузина Л. Б., Любимова С. В., Шайхутдинова А. Ф. Техника для снижения сил трения при бурении горизонтальных участков скважин // Нефтепромысловое дело. 2016. № 9. С. 38-42.

15. Оганов С. А., Байсаров Э. Э., Лабазанов С. Х. Достижение высоких технико-экономических показателей строительства горизонтальных скважин // Проблемы экономики и управления нефтегазовым комплексом. 2012. № 5. С. 126-132.

Поступила в редакцию 7 апреля 2020 года

\section{Сведения об авторах:}

Курячий Александр Евгеньевич - аспирант Института нефти и газа Астраханского государственного технического университета. E-mail: kuryachiy.aleksandr@mail.ru Калягин Сергей Михайлович - кандидат геолого-минералогических наук, доцент, доцент кафедры геологии нефти и газа Астраханского государственного технического университета. E-mail: kalyagin-sergey@lenta.ru

Для цитирования: Курячий А. Е., Калягин С. М. Применение современных технологических средств в области бурения наклонно-направленных скважин с протяженными горизонтальными стволами // Известия вузов. Горный журнал. 2020. № 5. C. 13-18 (In Eng.). DOI: 10.21440/0536-10282020-5-13-18

For citation: Kuriachii A. E., Kaliagin S. M. Applying modern technologies when drilling directional wells with long horizontal boreholes. Izvestiya vysshikh uchebnykh zavedenii. Gornyi zhurnal = News of the Higher Institutions. Mining Journal. 2020; 5: 13-18. DOI: 10.21440/0536-1028-2020-5-13-18 